\title{
False aneurysm of the radial artery: Unusual complication of both-bone forearm fracture in children: $A$ case report A Amrani*1, MA Dandane ${ }^{2}$, Z El Alami², T El Madhi², H Gourinda² and A Miri
}

Address: ${ }^{1} 16$ allee safsaf, Amal II/01, Riyad, Rabat 10100, Morocco and 2Paediatric orthopaedics' Unit, Children's hospital, Rabat 10100, Morocco Email: A Amrani* - amraniabdel@menara.ma; MA Dandane - damdendane@yahoo.fr; Z El Alami - elalamiz@gmail.com; T El Madhi - elmdhitariq@menara.ma; H Gourinda -ggourinda@menara.ma; A Miri - miri@menara.ma

* Corresponding author

Published: 19 September 2008

Cases Journal 2008, I:170 doi:10.1 186/1757-1626-1-170

This article is available from: http://www.casesjournal.com/content/I/I/I70

(c) 2008 Amrani et al; licensee BioMed Central Ltd.

This is an Open Access article distributed under the terms of the Creative Commons Attribution License (http://creativecommons.org/licenses/by/2.0), which permits unrestricted use, distribution, and reproduction in any medium, provided the original work is properly cited.
Received: II June 2008

Accepted: 19 September 2008

\begin{abstract}
False aneurysm or pseudo aneurysm of an artery in close proximity to fractured bone is a wellrecognized entity, and fewer various cases, involving different sites have been reported in the literature. We report new case of a Moroccan's patient who had 10-year-old boy presented with a right non displaced both-bone forearm fracture; the patient was placed in a long arm splint. After, six weeks, the cast was removed. And a pulsatile mass on the volar-radial aspect of the forearm was decouvred. The mass was non-tender and the patient had radial and ulnar pulse. An Ultrasound and brachial angiography showed a false aneurysm of distal radial and the radial artery was ligated.

In conclusion, pseudoaneurysm of the radial artery can be associated with any bone fracture despite non displacing fractures related to the elasticity of the bone in this age and orthopedic surgeons should be aware of this potential complication.
\end{abstract}

\section{Background}

The most common causes of radial pseudo aneurysm in children and adolescents are penetrating trauma and iatrogenic arterial injury. False aneurysm or pseudo aneurysm of the artery in close proximity to the fractured bone is a well-recognized case, and a few other cases, involving different locations have been reported in literature [1-5]. We report the case of a patient with false aneurysm of the Radial Artery after a both-bone forearm fracture. As far as we know, only one such case had been previously reported in the literature [6].

Vascular complications following paediatric both bone forearm fractures are rare. This article presents a case of a non displaced both-bone forearm fracture in a child treated with a cast.

\section{Case report}

A 10-year-old boy had a both-bone right forearm fracture from a fall with the outstretched hand. Examination revealed a closed injury with normal distal radial and ulnar pulses and intact sensation with no associated medical history or other clinical finding. Plain radiographs of the forearm (Figure 1) demonstrated a non-displaced both-bone radius and ulnar fracture and the patient's arm was placed in a long arm splint.

Six weeks later, the cast was removed. Examination demonstrated a $20-\mathrm{mm}$ diameter fluid-filled pulsatile mass on the volar-radial side of the forearm approximately $4 \mathrm{~cm}$ from the wrist joint. The forearm and mass were non-tender and the patient had radial and ulnar pulse. 


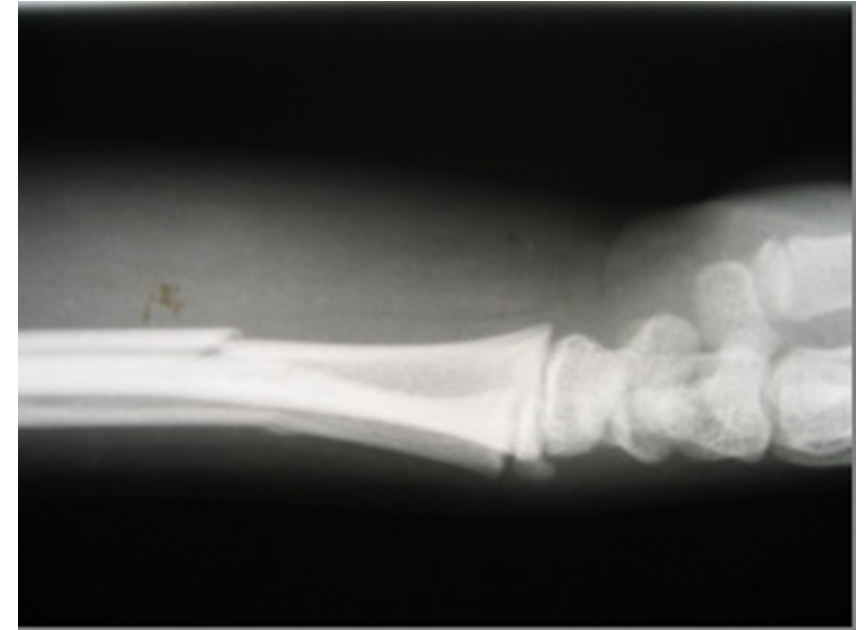

Figure I

Plain radiographs of the forearm demonstrated a non-displaced both-bone radius and ulnar fracture.

Radiographs demonstrated adequate alignment, a healing fracture and a good periosteal callus. Ultrasound was consistent with pseudoaneurysm of the right radial artery. Brachial angiography was performed to the patient. False aneurysm of distal radial artery was observed (Figure 2).

A $4 \mathrm{~cm}$ longitudinal incision was made directly over the mass. The mass was directly volar to the radial artery and extended into the subperiosteal tissues. After the mass was freed of fibrous connections, it was excised, and the radial artery was ligated (Fig. 3). The patient did well postoperatively without any further complication. 3 years after sur-

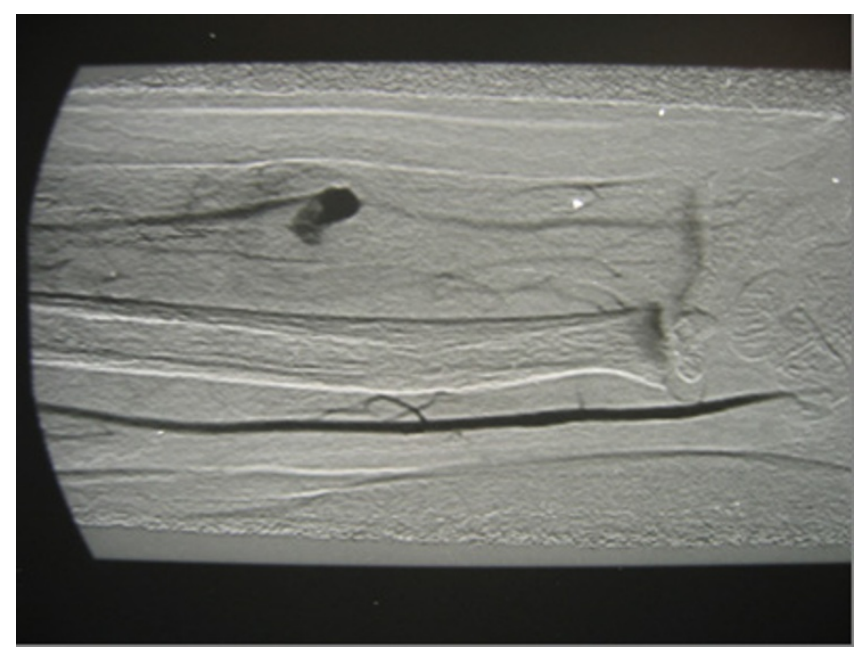

\section{Figure 2}

A brachial angiography show a false aneurysm of distal radial artery.

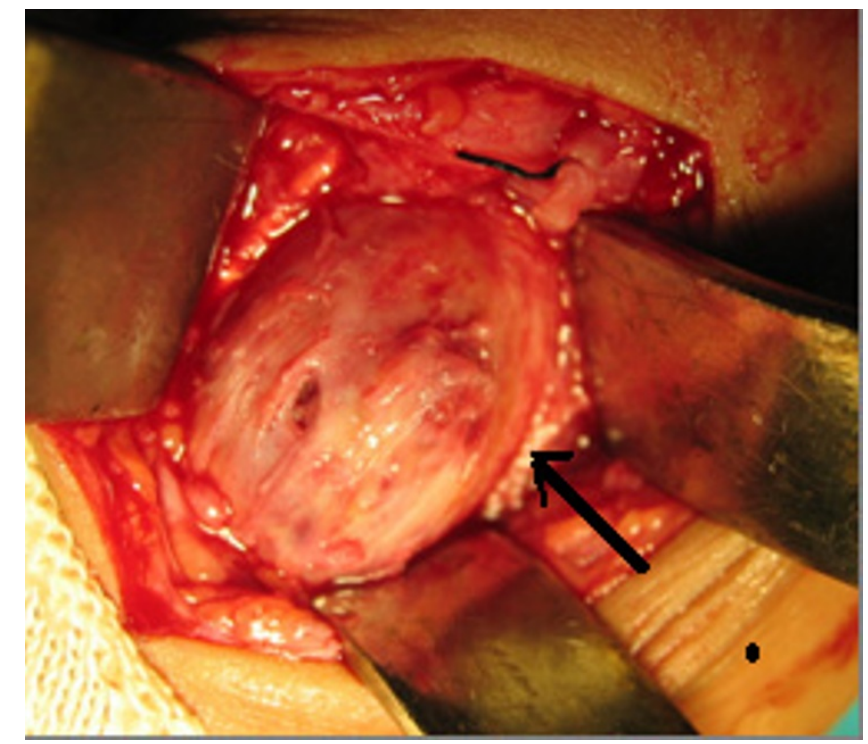

Figure 3

The mass was directly volar to the radial artery and extended into the subperiosteal of the radial sheath and the radial artery ligated.

gery, the patient remains symptom free with normal growth and function of the hand.

\section{Discussion}

The most common causes of radial pseudo aneurysm in children and adolescents are penetrating trauma and iatrogenic arterial injuries $[7,8]$. These vascular complications may occur within hours or months after the fracture. A pseudoaneurysm of an arterial vessel occurs after a fullthickness laceration from either blunt or penetrating trauma, from lacerations, or from complications arising from fracture fixation plates [1-3,6,9]. A vessel injury allows for extravasation of blood into the surrounding tissues with ensuing formation of a fibrous capsule. The artery usually remains patent due to the remaining inherent cylindrical structure of the artery, which prevents contraction and collapse. Thus the wall of the pseudoaneurysm is fibrous in nature and lacks an intima layer associated with native arteries. Blood is usually clotted to some degree within this fibrous wall and, in many cases; the entire mass will be pulstile owing to the patency of blood flow into the lumen of the pseudoaneurysm [59]. Despite a non-displaced bone fracture in our case, the occurrence of false aneurysm can be explained by the high degree of bone plasticity in this age and the artery was punctured by a fractured bone speculate before returning to its original position.

Operative treatment of pseudoaneurysms are not well defined. However, surgical treatment is recommended 
depending on their location, size, symptoms, and association with an important artery $[6,8,10]$. Observation has been recommended for asymptomatic pseudoaneurysms $<10 \mathrm{~mm}$ in diameter, which involve arteries of only minor importance. 14 Pseudoaneurysms that are larger in size $(>10 \mathrm{~mm})$, located in an area that is predisposed to injury or associated with an important artery, should be operated surgically. Many surgical modalities have been described, including ligation or resection, direct repair, embolization or angioplasty, and vein grafting. The exact technique depends on location of the mass and the exact association with the vessel $[6,13]$.

Other authors support simple ligation of radial artery and excision of the pseudo aneurysm if adequate collateral flow is observed. This treatment strategy is considered satisfactory even in the paediatric population $[14,15]$. We elected surgical treatment due to the fact that the patient was symptomatic, and then decided to ligate the radial artery since the vascular supply to the hand was assured by collateral circulation.

In summary, pseudoaneurysm of the radial artery can be associated with a forearm bone fracture despite non-displaced fractures related to the elasticity of the bone in this age and orthopaedic surgeons should be aware of this potential complication following a fracture of the bone forearm.

\section{Competing interests}

The authors declare that they have no competing interests.

\section{Authors' contributions}

AA: Operated, fellowed the case and wrote the manuscript. All others authors have read and improved the manuscript.

\section{Consent}

A written informed consent was granted by the parents for publication of this case report and accompanying images. A copy of the written consent is available for the review of the Editor-in-Chief of this journal.

\section{References}

I. Yang KH, Park HW, Park S): Pseudoaneurysm of the superficial femoral artery after closed hip nailing with a Gamma nail: report of a case. J Orthop Trauma 2002, 16:124-127.

2. Sotheran WJ, Perry PM: A complication after internal fixation of fracture. Postgrad Med J 200I, 77:209-214.

3. Van Arkel ER, Tordoir JH, Arens HJ: A proximal humeral fracture, complicated by a pseudoaneurysm - a case report. Acta Orthop Scand 1998, 69:194-195.

4. Stephen DJ: Pseudoaneurysm of the superior gluteal arterial system: an unusual cause of pain after a pelvic fracture. J Trauma 1997, 43:| 146-I49.

5. Murphy PG, Geoghegan JG, Austin O, More-O'Ferrall R, Quinlan WR, Keaveny TV: Pseudoaneurysm of the profunda femoris artery due to intertrochanteric fracture of the hip. Arch Orthop Trauma Surg 1999, I 19: I 17-1 18.
6. Provencher MT, Maurer C, Thompson M, Hofmeister E: Operative grafting of a Pseudoaneurysm of the Radial Artery after a Pediatric both-bone Forearm Fracture. Orthopedics 2007, 30:874.

7. Harris O, Roche CJ, Torreggiani WC, Ritchie DA, Jane M, McWilliams $R$, Munk PL: Delayed presentation of pseudoaneurysm complicating closed humeral fracture: MR diagnosis. Skeletal Radiol 200I, 30:648-65I.

8. Pai VS: Traumatic aneurysm of the perforating peroneal artery following ankle fracture. I Foot Ankle Surg 1999, 38:417-4I9.

9. Dao KD, Venn-Watson E, Shin AY: Radial artery pseudoaneurysm complication from use of AO/ASIF volar distal radius plate: a case report. J Hand Surg [Am] 200I, 26:448-453.

10. Wolford H, Peterson SL, Ray C, Morgan SJ: Delayed arteriovenous fistula and pseudoaneurysm after an open tibial fracture successfully managed with selective angiographic embolization. J Trauma 200I, 5 I:78|-783.

II. Moufarrege R, Teot L, Beauregard GN, Bosse JP, Papillon J: Pseudoaneurysms of the radial artery. Importance of microsurgery. Apropos of a case. Ann Chir Main 1982, 1:40-44.

12. Wang AA, Strauch RJ, Moore JA: Pseudoaneurysm of the ulnar artery occurring after fracture of the distal radius and ulna: a case report. J Hand Surg [Am] 1998, 23:933-937.

13. Dhal A, Chadha M, Lal H, Singh T, Tyagi S: Encounters with pseudoaneurysms in orthopaedic practice. Injury 200I, 32:77I-778.

14. Zitsman JL: Pseudoaneurysm after penetrating trauma in children and adolescents. J Pediatr Surg 1998, 33:1574-I 577.

15. Votapka T, Backer $\mathrm{Cl}$, Mavroudis $\mathrm{C}$ : Giant popliteal false aneurysm in an 8-year-old child. J Pediatr Surg 1993, 28:1594-1596. Publish with Bio Med Central and every
scientist can read your work free of charge

"BioMed Central will be the most significant development for disseminating the results of biomedical research in our lifetime. " Sir Paul Nurse, Cancer Research UK

Your research papers will be:

- available free of charge to the entire biomedical community

- peer reviewed and published immediately upon acceptance

- cited in PubMed and archived on PubMed Central

- yours - you keep the copyright 